\title{
Przestrzenne zróżnicowanie wysokości cen żyta, pszenicy, jęczmienia i owsa na terenie Królestwa Polskiego w lustracjach królewszczyzn z lat 1564-1565
}

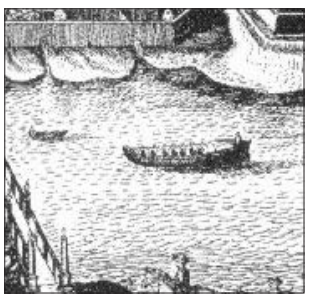

\author{
(http://atlasfontium.pl/index.php?article=ceny_zboz) \\ Krzysztof Boroda
}

https://orcid.org/0000-0002-9423-2990

Uniwersytet w Białymstoku

\begin{abstract}
Zarys treści: Artykuł jest analizą przestrzennego rozmieszczenia cen czterech zbóż (pszenicy, żyta, jęczmienia i owsa) opracowanego na podstawie informacji zawartych w lustracjach majątków królewskich. Porusza także problem ich wiarygodności. Zgromadzone dane obejmują całe terytorium Królestwa Polskiego w granicach sprzed 1569 r. oraz włączone do niego w 1569 r. Podlasie.
\end{abstract}

Słowa kluczowe: historia gospodarcza, geografia gospodarcza, historia cen

Największe triumfy polskiej historiografii w badaniu cen przypadają na okres międzywojenny. Podobnie jak wielu badaczy z innych krajów europejskich grupa skupiona wokół Franciszka Bujaka podjęła wówczas działania mające na celu przebadanie europejskiej rewolucji cen między XV a XVII w. Zakładano, że prace będą się odbywały w dwóch etapach. W pierwszym badacze chcieli stworzyć i opublikować zbiory danych o cenach i płacach w wybranych miastach Rzeczypospolitej: Gdańsku, Krakowie, Warszawie, Lwowie, Lublinie, Poznaniu, Toruniu i Wilnie, poczynając od średniowiecza, a kończąc na schyłku wieku XVIII. Po skompletowaniu tych danych planowano przeprowadzić ich syntetyczną analizę, pozwalającą na ocenę skali tego zjawiska na ziemiach polskich w kontekście europejskim. Do wybuchu wojny w 1939 r. opublikowane zostały zestawienia cen z Gdańska, Krakowa,
Abstract: The article deals with the analysis of the spatial distribution and reliability of information on the prices of four cereals (wheat, rye, barley and oats) included in the survey of crown lands. The collected data cover the entire territory of the Kingdom of Poland within the borders prior to 1569 , and the area of Podlasie incorporated in 1569 .

Keywords: economic history, economic geography, prices history

Warszawy, Lwowa i Lublina ${ }^{1}$. W okresie powojennym, mimo dominacji paradygmatu marksistowskiego, który kładł nacisk na prowadzenie badań w odniesieniu do sfery materialno-gospodarczej, prace nad cenami zostały niemal zupełnie zarzucone. Jedyną publikacją, która odpowiadała swą formą tekstom przedwojennym, było opracowane przez Mariana Wolańskiego zestawienie wrocławskich cen z lat 1506-1618, wydane dopiero w latach 1993-19962. Zaawansowane badania cen z Poznania, Torunia i Wilna zostały utracone w czasie wojny, a próby ich ponownego

${ }^{1}$ W. Adamczyk, Ceny w Lublinie od XVI do końca XVIII wieku, Lwów 1935; J. Pelc, Ceny w Krakowie w latach 1369-1600, Lwów 1935; E. Tomaszewski, Ceny w Krakowie w latach 1601-1795, Lwów 1934; S. Hoszowski, Ceny we Lwowie w XVI i XVII wieku, Lwów 1928; W. Adamczyk, Ceny w Warszawie w XVI I XVII wieku, Lwów 1938; J. Pelc, Ceny w Gdańsku w XVI i XVII wieku, Lwów 1937; T. Furtak, Ceny w Gdańsku w latach 1701-1815, Lwów 1935.

${ }^{2}$ M. Wolański, Ceny zboża i jego przetworów oraz owoców i warzyw we Wrocławiu w latach 1506-1618, Wrocław 1993; tenże, Ceny we Wrocławiu w latach 1506-1618, Wrocław 1996. 
opracowania nie przyniosły efektu w formie publikacji zestawień.

W 1958 r. na VIII Powszechnym Zjeździe Historyków twórca wydanych w okresie międzywojennym zestawień lwowskich cen z XVI-XVII w., Stanisław Hoszowski, zgłosił postulat, by mimo nieukończenia zestawień cen przeprowadzić planowaną syntezę badawczą zjawiska ich ruchu na ziemiach Królestwa Polskiego w XVI-XVIII w. w oparciu o dane z pięciu ośrodków miejskich, wzbogacone dodatkowo informacjami z rachunków ekonomii malborskiej ${ }^{3}$. W dyskusji nad wystąpieniem Hoszowskiego krytyczne uwagi podniósł Witold Kula, kładąc nacisk na trzy rzeczy. Po pierwsze, na niekompletny charakter opublikowanych w międzywojniu zestawień, w których wielokrotnie wyliczenia średnich cen z poszczególnych lat opierały się na pojedynczych wzmiankach źródłowych (co zresztą jako mankament wskazywał sam Hoszowski). Po drugie, na niepewną jego zdaniem wiarygodność indeksów łańcuchowych cen wyliczonych przez twórców zestawień, wynikającą z uwzględniania w nich nie pojedynczych produktów, ale całych grup, czy też tworzenia średnich dla pięcioletnich przedziałów w oparciu o tylko jedną wzmiankę źródłową. Po trzecie zaś, nie negując ważności badań porównawczych ruchów cen w najważniejszych ośrodkach miejskich w skali kraju i Europy, wskazywał na dużo istotniejszą jego zdaniem potrzebę analiz niediachronicznych, pozwalających uchwycić zależności, które występowały w obrębie rynków lokalnych oraz między rynkami lokalnymi a regionalnymi poprzez rozpiętości cen między nimi. Aleksy Gilewicz wskazał z kolei, że istotnym problemem w badaniu cen jest brak informacji o wielkości poszczególnych

${ }^{3}$ S. Hoszowski, Rewolucja cen w Polsce w XVI-XVII wieku, w: VIII Powszechny Zjazd Historyków Polskich. Referaty i dyskusje, t. 2: Historia gospodarcza Polski, red. N. Gąsiorowska, Warszawa 1960, s. 105-120. Tekstowi wystąpienia towarzyszy dyskusja, w której głos zabrali m.in. Witold Kula i Aleksy Gilewicz. Tamże, s. 120-140. miar w analizowanym okresie i ich wzajemnych relacjach, co uniemożliwia całościowe spojrzenie na rynek.

Ostatecznie nikt z polskich historyków nie pokusił się o dokonanie syntetycznego ujęcia procesu rewolucji cen na ziemiach polskich w późnym średniowieczu i czasach nowożytnych, aczkolwiek same zestawienia cen stworzone przez uczniów Franciszka Bujaka wykorzystywane były intensywnie przez wielu badaczy przy różnych okazjach. W dorobku polskiej historiografii zasadniczo jedynie trzy prace można uznać za skupiające się na badaniu cen i ich zmian w czasie i przestrzeni: Jana Szpaka na temat związku między procesem wzrostu cen płodów rolnych w XVI w. a gospodarką dworską w starostwach Prus Królewskich ${ }^{4}$, Heleny Madurowicz-Urbańskiej o cenach zboża w osiemnastowiecznej Małopolsce ${ }^{5}$ oraz studium na temat funkcjonowania rynku zbożowego na ziemiach polskich w wieku XVI i na początku XVII autorstwa Stanisława Mielczarskiego $^{6}$. O ile jednak prace Szpaka i Madurowicz-Urbańskiej są analizami procesu zmiany cen produktów rolnych na terenie rynków regionalnych Prus Królewskich i części Małopolski oraz związanych z tym zmian w profilu aktywności gospodarczej i dochodowości majątków królewskich, to studium Mielczarskiego oferuje nam opartą na lustracjach królewszczyzn analizę wzajemnych relacji cen kluczowych dla ówczesnej gospodarki zbóż (owsa i żyta), obejmującą znakomitą większość Królestwa Polskiego w dwóch przedziałach chronologicznych - 1564-1565 i $1616-1620$.

Obok nich informacje o cenach i płacach w pojedynczych miejscowościach czy regionach pojawiają się $\mathrm{w}$ publikacjach

\footnotetext{
${ }^{4}$ J. Szpak, Rewolucja cen XVI wieku a funkcjonowanie gospodarki dworskiej w starostwach Prus Królewskich, Kraków 1982.

${ }^{5}$ H. Madurowicz-Urbańska, Ceny zboża w zachodniej Małopolsce w drugiej połowie XVIII wieku, Warszawa 1963.

${ }^{6} \mathrm{~S}$. Mielczarski, Rynek zbożowy na ziemiach polskich w drugiej połowie XVI i pierwszej połowie XVII wieku. Próba rejonizacji, Gdańsk 1962.
} 
z zakresu historii gospodarczej. Zawarte w nich dane ograniczone są jednak zwykle do pojedynczych lat bądź bardzo krótkich przedziałów czasowych. Jedynie w nielicznych przypadkach autorzy podejmowali próby obejmowania analizą szerszego terytorium, z czym mamy do czynienia w publikacjach Antoniego Mączaka poświęconych badaniom nad traktowanymi jako jednorodny obszar badań cenami, płacami i kosztami utrzymania w Królestwie Polskim w XVI-XVII w. ${ }^{7}$ Jako odrębną grupę należy traktować studia syntetyczne oparte na powstałych wcześniej zestawieniach cen, np. prace Stanisława Hoszowskiego $^{8}$, Jana Gurgula9 czy też Antoniego Maczaka ${ }^{10}$. Spośród wszystkich tych publikacji najbliżej postulatów zgłoszonych w 1957 r. przez Kulę lokują się oparte na danych o cenach i płacach zawartych w lustracjach dóbr królewskich prace Mielczarskiego i Mączaka, obejmujące analizą większość bądź całość terytorium Królestwa Polskiego. Zważywszy na niejednorodność chronologiczną informacji o cenach i płacach pojawiających się w źródłach inwentarzowych i rachunkowych, lustracje dóbr królewskich wydają się wręcz wymarzoną krynicą informacji o cenach, płacach i kosztach, oferującą dane dla całego terenu państwa w niezbyt odległych przedziałach czasowych. W tym miejscu rodzi się oczywiście pytanie o wiarygodność danych na temat cen przytaczanych przez lustratorów. Przede wszystkim należy

\footnotetext{
${ }^{7}$ A. Mączak, Place i pieniądze w gospodarce rolnej Polski XVI-XVII wieku. Problem niedoceniany, , Zapiski Historyczne”, 41 (3), 1976, s. 51-65; tenże, Ceny, płace i koszty utrzymania w Europie Środkowej. W poszukiwaniu nowych źródeł do dziejów XVI wieku, „Przegląd Historyczny”, 64 (4), 1973, s. 741-769.

${ }^{8}$ S. Hoszowski, Rewolucja cen w środkowej Europie w XVI iXVII w., ,Kwartalnik Historyczny", 68 (2), 1961, s. 297-312

${ }^{9} \mathrm{~J}$. Gurgul, Ceny czterech podstawowych zbóż w XVI wieku. Próba porównania, „Rocznik Muzeum Narodowego Rolnictwa w Szreniawie”, 17, 1989, s. 319-337.

${ }^{10} \mathrm{~A}$. Mączak, Export of grain and the problem of distribution of national income in the years 1550-1650, „Acta Poloniae Historica”, 18, 1968, s. 75-98; tenże, Pieniądz i społeczeństwo w Rzeczpospolitej XVI-XVII wieku, „Roczniki Dziejów Społecznych i Gospodarczych”, 37, 1977, s. 63-85; tenże, Z metodyki badań rynku w XVI-XVII wieku. Uwagi polemiczne, „Kwartalnik Historii Kultury Materialnej", 12 (4), 1964, s. 681-707.
}

sobie uświadomić, że celem działań lustratorów nie było precyzyjne rejestrowanie lokalnych cen na terenie kraju, ale ustalenie dochodowości majątków królewskich z produkcji folwarcznej i określonych danin pobieranych od ludności wiejskiej. Nie chodziło przy tym o dokładny poziom dochodów w konkretnym roku, ale o dochód uśredniony, uwzględniający duże wahania w różnych latach ${ }^{11}$. W opinii większości badaczy korzystających z lustracji - np. Stanisława Mielczarskiego, Andrzeja Wyczańskiego, Alicji Falniowskiej-Gradowskiej czy wydawców tych dokumentów - podawane w nich ceny były zgodne z rzeczywistymi ${ }^{12}$. Nie zgadzali się jednak w pełni, czy chodziło o kwoty minimalne, średnie czy przeciętne i czy odnosity się one do całego roku, czy tylko do jego części. Radykalnie odmienną opinię wyrażała natomiast Irena Rychliko$w^{13}$. Posiłkując się szeregiem informacji z diariuszy sejmowych, twierdziła, że ceny używane w ostatecznych wersjach lustracji do kalkulowania dochodowości majątków królewskich ustalane były w trakcie obrad sejmowych, w związku z czym unifikowano je na dużych obszarach. Takim właśnie zabiegiem tłumaczyła obserwowaną w całej Małopolsce (województwach krakowskim, sandomierskim i lubelskim) jednolitość cen czterech podstawowych zbóż, dla których punktem wyjścia były jej zdaniem ceny z krakowskiego rynku regionalnego. Podobnie uznała, że ceny wymienione w lustracjach ziem ruskich zunifikowano

\footnotetext{
${ }^{11}$ Andrzej Wyczański wskazuje na olbrzymie niekiedy różnice w poziomie towarowości produkcji zbożowej folwarków w poszczególnych, nawet bardzo bliskich sobie latach. A. Wyczański, Studia nad gospodarką starostwa korczyńskiego 1500-1660, Warszawa 1964, s. 58-66.

${ }^{12}$ S. Mielczarski, Rynek, S. 27-33; A. Wyczański, Studia nad folwarkiem szlacheckim w Polsce w latach 1500-1580, Warszawa 1960, s. 228-231; A. Falniowska-Gradowska, Miary zbożowe w województwie krakowskim w XVIII w., „Kwartalnik Historii Kultury Materialnej”, 13 (4), 1965, s. 666; Lustracja województwa sandomierskiego 1564-1565, wyd. W. Ochmański, Wrocław-Warszawa-Kraków 1963, s. XXVI.

${ }^{13}$ I. Rychlikowa, Lustracja 1564-1566 jako podstawa szacunków dochodów z gospodarki polowej, „Kwartalnik Historii Kultury Materialnej”, 22 (4), 1974, s. 673-716; taż, Niektóre zagadnienia metodyczne w badaniach cen i rynku w drugiej połowie XVIII wieku, „Kwartalnik Historii Kultury Materialnej", 12 (1), 1964, s. 375-409.
} 
na sejmie lubelskim 1566 r., przyjmując w kalkulacjach za punkt odniesienia łaszt zboża miary gdańskiej i arbitralnie ustalając jego cenę przeliczeniową na $13 \mathrm{zł}$ i 15 gr dla żyta (początkowo $15 \mathrm{zł}$ ) oraz 18 zł dla pszenicy (pierwotnie 19 zł) ${ }^{14}$. Jak wynika z jej wywodów, dotyczyło to jednak tylko terenów położonych w bezpośrednim sąsiedztwie Bugu. Odnośnie do Prus Królewskich Rychlikowa wskazała na zabiegi unifikacyjne polegające na jednolitym zastosowaniu dla całego ich terytorium łaszta gdańskiego wraz z jego jednolitą wyceną, przy czym zastosowana cena była jej zdaniem niewspółmiernie wysoka w porównaniu do rzeczywistych cen rejestrowanych w Gdańsku i Malborku (26 zł za łaszt żyta w lustracji wobec przeciętnej ok. $20 \mathrm{zł} \mathrm{w}$ zestawieniach Juliana Pelca). W przypadku Mazowsza za zabieg unifikacyjny uznała stosowanie przez lustratorów jednolitej ceny korca zboża dla całego terenu przy jednoczesnym braku unifikacji samego korca i operowaniu miarami lokalnymi. Wyliczone przez Rychlikową ceny jednego łaszta żyta miary gdańskiej dla ziem ruskich, Małopolski, Mazowsza i Prus Królewskich wskazują jednoznacznie, że ewentualne unifikowanie cen zasadniczo nie stało w sprzeczności z uwarunkowaniami rynkowymi. Wyliczone przez nią ceny łaszta żyta wynosiły: dla ziem ruskich - 13 zł i 15 gr, dla Mazowsza - 13-18 zł, dla Małopolski - 20 zł, a dla Prus Królewskich -26 zł $^{15}$. Tę ostatnią cenę uznała jednak za nierealną, gdyż znacznie przekraczała średnie ceny rejestrowane na Żuławach i w Gdańsku ${ }^{16}$. W swych rozważaniach zupełnie pominęła terytorium Wielkopolski, tłumacząc to brakiem opracowania miar zbożowych $\mathrm{z}$ tego regionu, oraz ziemie ruskie leżące z dala od Bugu. Ostatecznie nie określiła jednoznacznie, z jakiego rodzaju cenami mamy do czynienia w lustracjach, co nie

\footnotetext{
${ }^{14}$ Taż, Lustracja, s. 706-707.

${ }^{15}$ Tamże, s. 707.

${ }^{16}$ Dla Żuław byłoby to nieco ponad 19 zł, a w przypadku Gdańska - ok. 20 zł.
}

zmienia faktu, że jej wywody nieodparcie sugerują, że są one mało wiarygodne.

Mając na uwadze powyższe, postawiono w niniejszym artykule dwa cele. Pierwszym jest stworzenie w miarę kompletnego przestrzennego zestawienia cen czterech zbóż, które były kluczowe w kalkulacjach dochodowości folwarków królewskich, tj. owsa, żyta, pszenicy i jęczmienia, oraz uczynienie ich porównywalnymi poprzez sprowadzenie do jednej wspólnej miary dzięki przeliczeniu wszystkich miar na system metryczny i wyliczenie ceny za 100 litrów zboża (z uwzględnieniem pominiętej przez Rychlikową Wielkopolski). Celem drugim jest natomiast zweryfikowanie zasadności formułowanych przez Rychlikową podejrzeń co do wiarygodności cen tych zbóż w lustracjach. Podstawą do wyliczenia cen zbóż są teksty lustracji z lat 1564-1565 opublikowane drukiem w latach 1959-1967, za wyjątkiem lustracji województw ruskich, w przypadku których wykorzystane zostały edycje wydane w latach 1895-1900 we Lwowie przez Mychajła Hruszewskiego oraz w 1890 r. w Kijowie przez Komisję Badania Dawnych Aktów działająca przy generale-gubernatorze kijowskim, podolskim i wołyńskim ${ }^{17}$. W przypadku Małopolski, Mazowsza i Prus Królewskich wielkości nasypnych miar zbożowych oparte zostały na szacunkach ich

\footnotetext{
${ }^{17}$ Lustracja województwa krakowskiego 1564, cz. 1-2, wyd. J. Małecki, Warszawa 1962; Lustracja województwa lubelskiego 1565, wyd. A. Wyczański, Wrocław-Warszawa 1959; Lustracja województwa mazowieckiego 1565 , cz. 1-2, wyd. I. Gieysztorowa, A. Żaboklicka, Warszawa 1967; Lustracja województwa pomorskiego 1565, wyd. S. Hoszowski, Gdańsk 1961; Lustracja województwa sandomierskiego; Lustracja województw wielkopolskich i kujawskich 1564-1565, cz. 1-2, wyd. A. Tomczak, C. Ohryzko-Włodarska, J. Włodarczyk, Bydgoszcz 1961; Lustracje województwa płockiego 1565-1789, wyd. A. Sucheni-Grabowska, S.M. Szacherska, Warszawa 1965; Lustracje województwa rawskiego 1565 i 1570, wyd. Z. Kędzierska, Warszawa 1959; Lustracja województw malborskiego i chełmińskiego 1565, wyd. S. Hoszowski, Gdańsk 1961; Apхивъ юго-заnадной Рocciu, ч. 7 , т. 2, Кіевъ 1890, s. 42-363; Жерела до істориї України-Руси, т. 1, ред. М. Грушевський, Львів 1895; tamże, т. 2, ред. М. Грушевський, Львів 1897; tamże, т. 3, ред. М. Грушевський, Львів 1900. Wykorzystanie odnośnie do ziem ruskich edycji Hruszewskiego wynika z faktu, że opierała się ona na wersji lustracji przygotowanej pierwotnie przez Krzysztofa Sokołowskiego, zawierającej ceny sprzed ingerencji, jakiej dokonano w tej kwestii na sejmie lubelskim $1566 \mathrm{r}$.
} 
pojemności zawartej w literaturze przedmiotu oraz ich relacjach względem miary krakowskiej (w Małopolsce) lub gdańskiej (na Mazowszu) zawartych w lustracjach. W przypadku ziem ruskich podstawą były relacje (bezpośrednie lub pośrednie - poprzez inne miary) części lokalnych miar do miary gdańskiej zawarte w lustracjach. W razie braku tego rodzaju informacji wykorzystane zostały dane o wielkości omłotu zbóż (przede wszystkim owsa). W przypadku miar wielkopolskich dodatkowo uwzględniono informacje o wzajemnych relacjach miar zawarte $w$ inwentarzach dóbr kościelnych z XVI w. oraz pochodzące z lustracji z pierwszej połowy XVII w. wiadomości o normach produkcji piwa w browarach folwarcznych (liczbie beczek wytwarzanych z jednej lokalnej jednostki miary zbożowej) i normach ładowności wozów w trakcie świadczenia podwód ${ }^{18}$. W ten sposób udało się uzyskać informacje o pojemności 107 lokalnych miar, które występują w lustracjach. Ceny dla wszystkich miar, których pojemność dało się oszacować, wyrażone zostały w groszach polskich i przeliczone $\mathrm{w}$ relacji do 100 litrów dla każdego z czterech podstawowych zbóż: owsa, żyta, jęczmienia i pszenicy. Efekty tych zabiegów prezentują mapy $1-4$, przy czym lokalizacja ceny na mapie przyporządkowana została do ośrodka miejskiego, od którego dana miara otrzymała nazwę, traktowanego jako punkt centralny jej lokalnego stosowania i miejsce, z którego realiów rynkowych

\footnotetext{
${ }^{18}$ Inwentarz dóbr i dochodów biskupów poznańskich r. 1564, wyd. E. Długopolski, w: Archiwum Komisji Historycznej, seria 2, t. 3, Kraków 1939, s. 267-348; Inwentarz dóbri dochodów biskupstwa wtocławskiego zr. 1534, wyd. B. Ulanowski, Kraków 1902; Inwentarz dóbr stołowych biskupstwa włocławskiego z roku 1582, wyd. L. Żytkowicz, Toruń 1953; Inwentarz dóbr stołowych biskupstwa włocławskiego z roku 1598, wyd. L. Żytkowicz, Toruń 1950; J. Topolski, Gospodarstwo wiejskie w dobrach arcybiskupstwa gnieźnieńskiego od XVI do XVIII wieku, Poznań 1958, s. 382-387; Lustracja województw wielkopolskich i kujawskich 1616-1620, cz. 1-2, wyd. Z. Górski, R. Kabaciński, J. Pakulski, Wrocław-Warszawa-Kraków 1994; Lustracja województw wielkopolskich i kujawskich 1628-1632, cz. 1-2, wyd. Z. Guldon, Wrocław-Warszawa-Kraków 1967, tamże, cz. 3, wyd. Z. Guldon, Bydgoszcz 1967. Na temat szacunku wielkości miar zbożowych w Wielkopolsce przygotowywana jest odrębna publikacja.
}

cena została hipotetycznie wywiedziona przez lustratorów. Generalny układ cen widoczny na mapach nie jest oczywiście zaskoczeniem. Wyraźna tendencja do ich wzrostu z południa na północ, w miarę zbliżania się wraz z biegiem dużych rzek do Gdańska, była już wcześniej konstatowana przez badaczy. Wyraźnie zwraca tu jednak uwagę fakt absolutnej unifikacji cen na terenie Małopolski, gdzie do kalkulacji dochodowości produkcji zbożowej folwarków w odniesieniu do wszystkich zbóż wykorzystano identyczne ceny. Kontrastuje to ze zróżnicowaniem lokalnych cen w pozostałych regionach kraju - najsilniejszym w Wielkopolsce i na ziemiach ruskich położonych $\mathrm{z}$ dala od Bugu. W przypadku ziem ruskich położonych w górnym biegu Bugu wyraźnie widać unifikację cen akcentowaną przez Rychlikową, ale dotyczy to przede wszystkim żyta, a ceny innych zbóż są zróżnicowane. By zweryfikować wiarygodność informacji o cenach zbóż zawartych w lustracjach, możemy porównać je z dostępnymi danymi o cenach zebranymi w zestawieniach opracowanych pod auspicjami Franciszka Bujaka odnośnie do dużych ośrodków miejskich: Krakowa, Gdańska, Lublina, Warszawy i Lwowa oraz cenami lokalnymi, które zawarte zostały w pracach na temat funkcjonowania gospodarstwa folwarcznego wielkiej własności. Zanim jednak tego dokonamy, należy zaznaczyć, że zgodnie z ustaleniami sejmowymi ceny podawane w lustracjach miały być tzw. cenami miernymi. Pojęcie to można uznać za odpowiadające cenie średniej, ale lepiej byłoby utożsamić je z ceną przeciętną ${ }^{19}$. Innymi słowy, może tu chodzić niekoniecznie o średnią arytmetyczną cen z jakiegoś okresu, ale o cenę, która najczęściej pojawiała się w transakcjach (dominująca). Lustratorzy z pewnością nie mieli pełnego

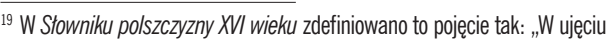
ilościowym: tyle ile trzeba, nie za dużo i nie za mało (zwłaszcza nie za dużo), przeciętnie, średnio". Stownik polszczyzny XVI wieku, red. M.R. Mayenowa, t. 14, Wrocław-Warszawa-Kraków-Gdańsk-Łódź 1982, s. 58.
} 
oglądu cen z lat poprzedzających ich pracę, ale zapisy w tekstach lustracji wskazują, że w wielu przypadkach dokonywali na miejscowych targach wywiadu na temat kształtowania się lokalnych cen. Niestety, za wyjąt kiem zestawień cen z części lat dla Krakowa i Gdańska, w przypadku żadnej innej miejscowości z terenu królestwa nie jesteśmy dziś w stanie określić średniej bądź przeciętnej ceny zbóż w XVI w. nawet w przybliżeniu. Informacje o cenach zbóż często ograniczają się bowiem do jednej wzmianki w roku, a odnośnie do niektórych lat brakuje ich nawet $\mathrm{z}$ dużych ośrodków. Zresztą także w przypadku Gdańska czy Krakowa, gdzie dla poszczególnych lat dysponujemy często większą liczbą wzmianek źródłowych, wyliczane średnie arytmetyczne nie są pewne, a to z uwagi na brak informacji o jakości zbóż. Ustalenie ceny przeciętnej nie jest zaś możliwe w ogóle, dlatego jedynym wyjściem wydaje się porównanie cen pojawiających się w lustracjach $\mathrm{z}$ ich przedziałami rejestrowanymi w latach dokonywania lustracji.

W przypadku miary krakowskiej lustratorzy stosowali konsekwentnie następujące ceny za jeden korzec: owies $-2,5 \mathrm{gr}$, żyto 6 gr, jęczmień -5 gr, pszenica -8 gr. W opracowanym przez Pelca zestawieniu dotyczącym okresu dokonywania lustracji i lat poprzedzających mamy natomiast następujące ceny za jeden korzec: owies 2,3-4,3 gr, przy czym cena dominująca wydaje się kształtować nieco poniżej $3 \mathrm{gr}$; żyto - 6-9 gr, przy najczęściej spotykanej cenie prawdopodobnie ok. 6,5 gr; jęczmień $-7-8$ gr; pszenica $-12-15$ gr $^{20}$.

W lustracji województwa mazowieckiego cena korca miary warszawskiej wynosiła: owies -5 gr, żyto -10 gr, jęczmień -8 gr, pszenica - 18 gr. Zebrane przez Władysława Adamczyka ceny jednego korca w Warszawie kształtują się natomiast następująco: owies - 5-8 gr, przy dominującej cenie prawdopodobnie ok. 6 gr; żyto -15 gr

${ }^{20}$ J. Pelc, Ceny w Krakowie, s. 7-13. (tylko jedna wzmianka z roku 1564, poza którą brak informacji z lat 1559-1569); jęczmień - 24 gr z pojedynczej wzmianki w 1566 r., przy cenie 7-8 gr w latach 1556-1557; pszenica - 9-30 gr, przy najczęstszych cenach w przedziale 13-19 $\mathrm{gr}^{21}$.

Jeden korzec miary lwowskiej wyceniany jest w lustracji na: owies $-2,5 \mathrm{gr}$, żyto -5 gr, jęczmień $-4,5$ gr, pszenica -8 gr. Zebrane przez Hoszowskiego dane dotyczące Lwowa wskazują natomiast na złożoną sytuację na lokalnym rynku zbożowym, gdzie w latach 1563-1564 mamy do czynienia $\mathrm{z}$ wyjątkowo niskimi cenami. Półmiarek owsa (odpowiadający korcowi z lustracji) kosztował wówczas 1,25-1,5 gr, a w drugiej połowie $1565 \mathrm{r}$. ceny wzrosły do 2,5-3 gr, co odpowiadało ich poziomowi z lat 1560-1562. Niestety, w odniesieniu do innych zbóż lwowskie ceny są mało miarodajne. $Z$ lat sześćdziesiątych XVI stulecia odnośnie do żyta dysponujemy jedynie dwiema wzmiankami z 1564 r. i pojedynczymi z lat 1566 i 1568. Ceny z czwartego (najtańszego) kwartału w 1564 i 1566 r. wynosity 3-3,25 gr za korzec, podczas gdy w pierwszym kwartale 1568 - 5,5 gr. W przypadku jęczmienia i pszenicy sytuacja jest jeszcze gorsza. Dla pszenicy nie dysponujemy w ogóle cenami z lat sześćdziesiątych XVI w., podczas gdy dla jęczmienia mamy z tego okresu tylko jedną wzmiankę z 1562 r., gdzie podano kwotę 4 gr za korzec ${ }^{22}$.

W przypadku miary lubelskiej porównanie cen z lustracji (wynoszących dla jednego korca owsa 5 gr, żyta - $10 \mathrm{gr}$, jęczmienia $-12 \mathrm{gr}$, a pszenicy $-16 \mathrm{gr}$ ) $\mathrm{z}$ cenami rejestrowanymi w Lublinie w latach sześćdziesiątych jest niemożliwe, ponieważ zebrane przez Adamczyka ciągi cen zbóż w tym ośrodku zaczynają się

\footnotetext{
${ }^{21}$ W. Adamczyk, Ceny w Warszawie, s. 8-13.

${ }^{22}$ S. Hoszowski, Ceny we Lwowie, s. 158-166. W nagtówkach tabel podających ceny pszenicy i jęczmienia prawdopodobnie błędnie jako jednostkę miary wpisano półmiarek (korzec). Tymczasem porównanie relacji cen jęczmienia i pszenicy z cenami owsa i żyta wskazuje wyraźnie, że chodzi o ceny kłody, która liczyła 8 korców.
} 


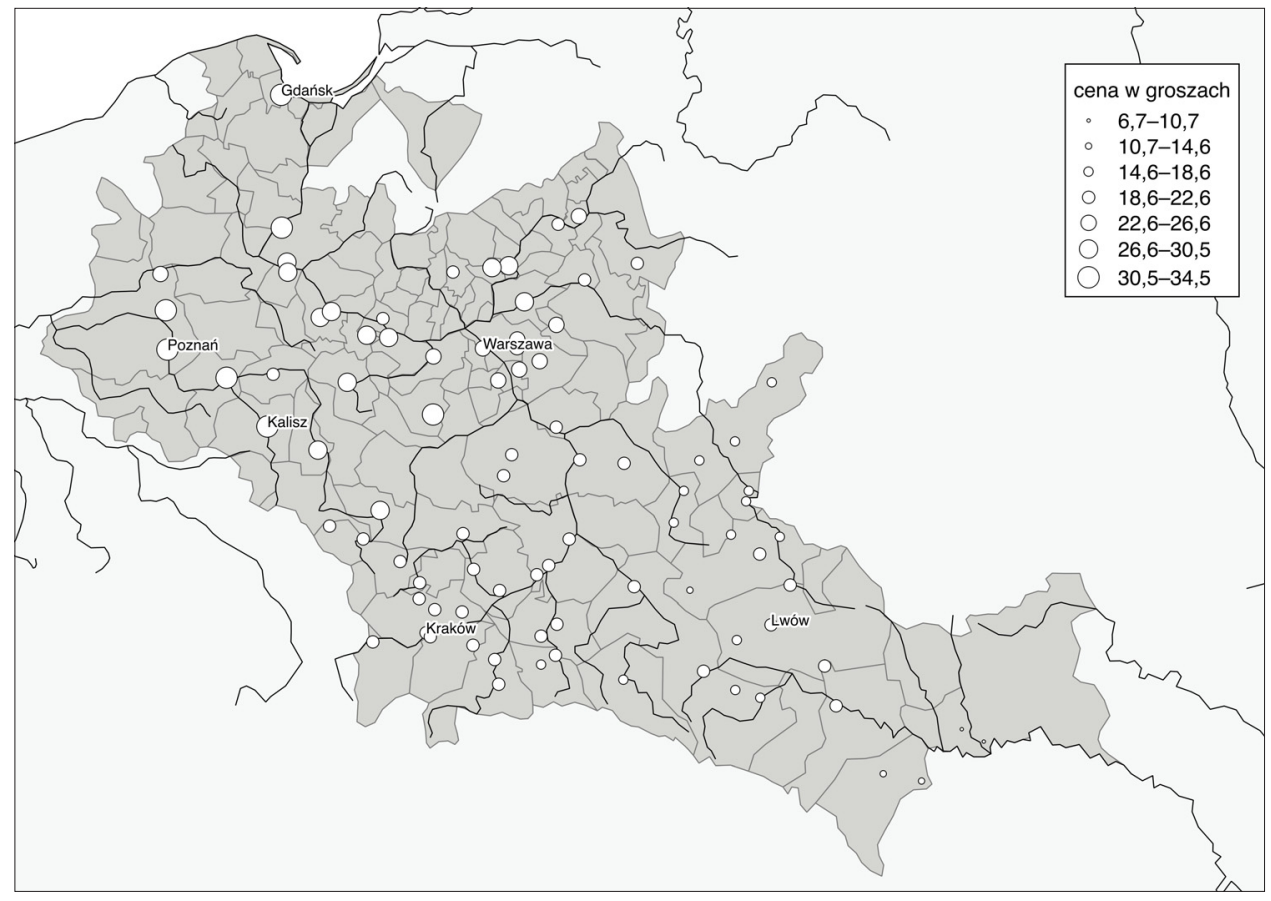

Mapa 1. Cena 100 litrów pszenicy (w groszach) według informacji zawartych w lustracjach dóbr królewskich z lat $1564-1565$

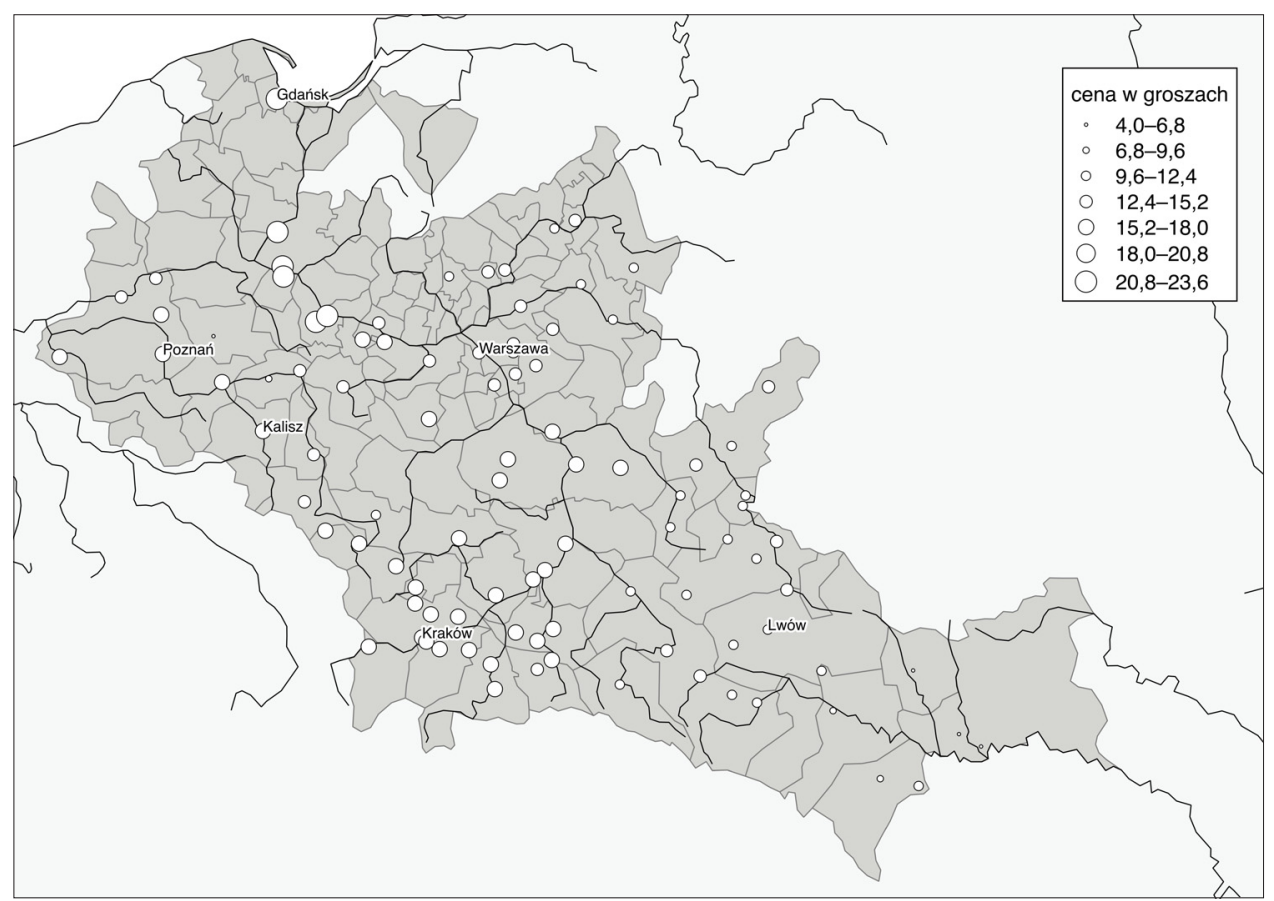

Mapa 2. Cena 100 litrów żyta (w groszach) według informacji zawartych w lustracjach dóbr królewskich z lat $1564-1565$ 


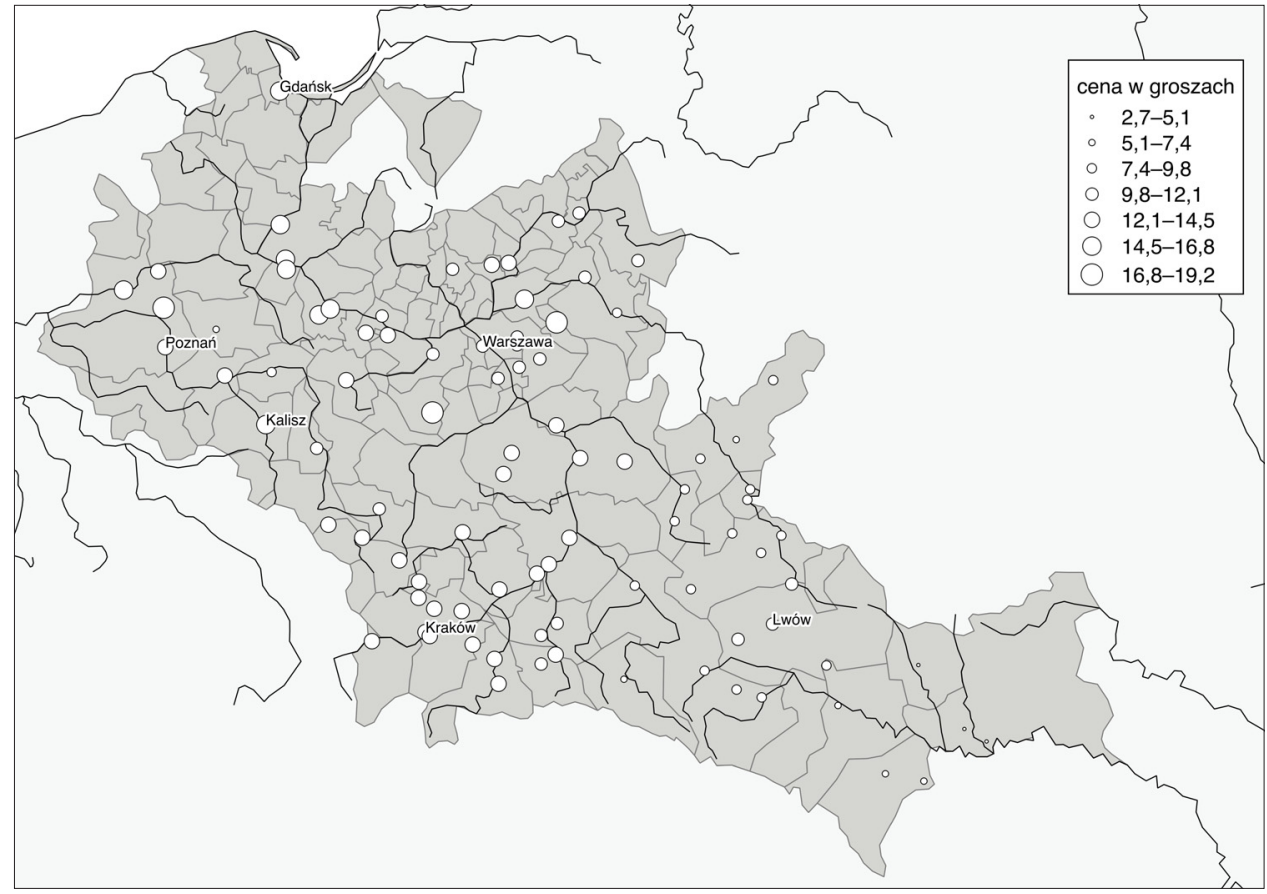

Mapa 3. Cena 100 litrów jęczmienia (w groszach) według informacji zawartych w lustracjach dóbr królewskich z lat $1564-1565$

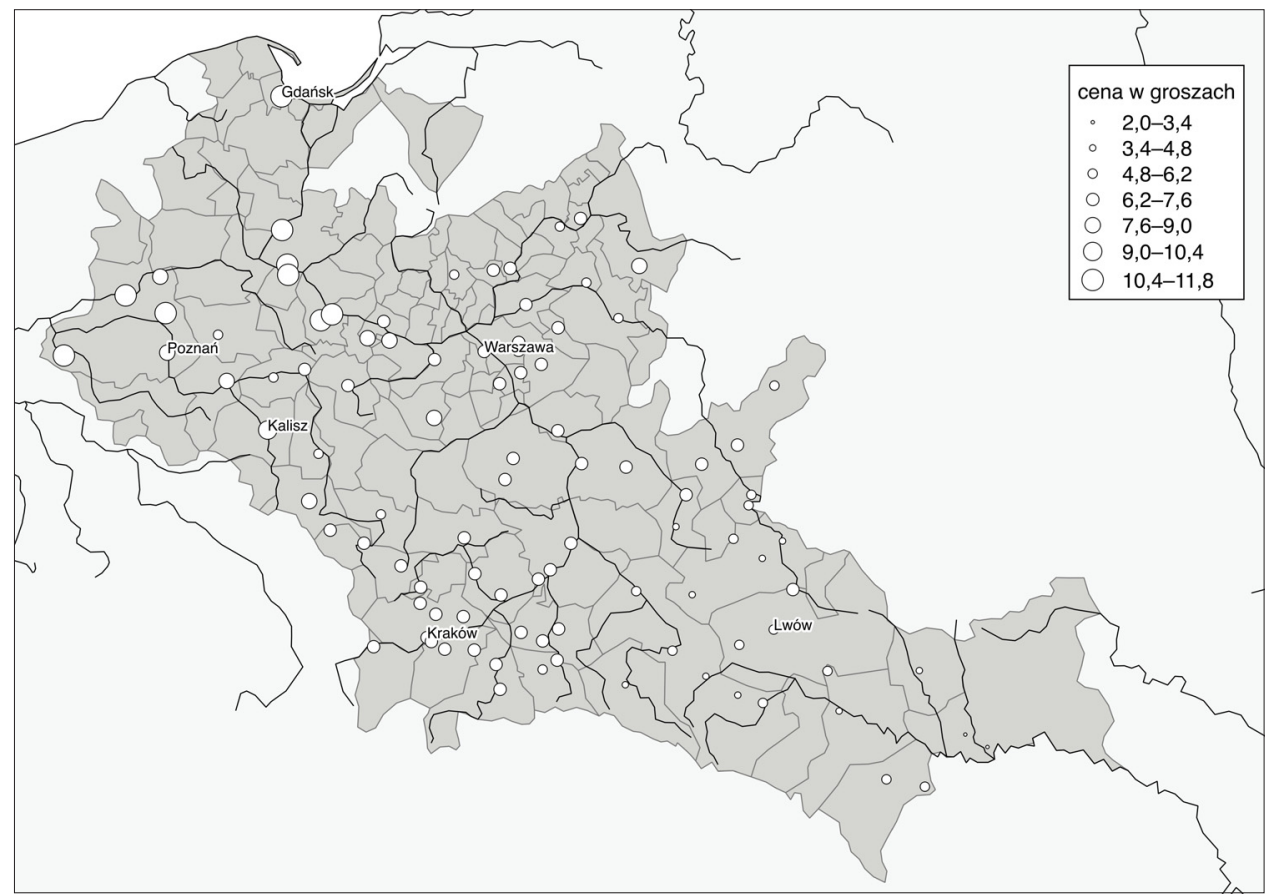

Mapa 4. Cena 100 litrów owsa (w groszach) według informacji zawartych w lustracjach dóbr królewskich z lat $1564-1565$

\section{2 studia Geohistorica • Nr 07.2019}


dopiero od 1570 r. Wyjściem z tej sytuacji byłoby porównanie lubelskich cen $\mathrm{z}$ tego roku (nominalnie prezentujących ten sam poziom co ceny widniejące w lustracji) z krakowskimi, jednak nie dysponujemy tymi drugimi. Porównania można dokonać dopiero odnośnie do roku 1573, w którym lubelskie i krakowskie ceny 100 litrów poszczególnych zbóż wynosiły odpowiednio: owsa - 9 i 13 gr, żyta - 17 i 26 gr, jęczmienia - 19,5 i 52 gr, pszenicy - 35 i 43 gr $^{23}$.

Jeżeli chodzi o Małopolskę, to porównania cen lustracyjnych $\mathrm{z}$ rzeczywistymi cenami lokalnymi pojawiającymi się w literaturze przedmiotu można dokonać jeszcze, odnosząc się do miar sandomierskiej i korczyńskiej, ale będzie to możliwe dla innych lat niż czas sporządzenia pierwszej lustracji. W przypadku miary sandomierskiej informacje zawarte w pracy Jadwigi Muszyńskiej Gospodarstwo chtopskie w starostwie sandomierskim 1510-1663 pozwalają dokonać tego w odniesieniu do cen owsa w roku $1567^{24}$. W przeliczeniu na 100 litrów tego zboża cena widniejąca w inwentarzu starostwa sandomierskiego z roku 1567 wynosiła 8,7 gr, a w Krakowie - 10-23 gr. W przypadku miary korczyńskiej istotnymi problemami są brak w szesnastowiecznych inwentarzach cen krakowskich z szeregu lat oraz dominacja praktyki sprzedaży zboża niemłóconego (w brogach) w starostwie korczyńskim. Powoduje to, że możemy porównać ze sobą jedynie korczyńskie i krakowskie ceny pszenicy z 1537 r. (odpowiednio 13,9 i 24,5 gr za 100 litrów), owsa z 1556 (6,5 i 6,5-10,5 gr), żyta z 1572 (17,3 i 25-75 gr) oraz pszenicy z 1572 (26 i 45,5-91 gr) ${ }^{25}$.

\footnotetext{
${ }^{23}$ W. Adamczyk, Ceny w Lublinie, s. 68-70.

24 J. Muszyńska, Gospodarstwo chłopskie w starostwie sandomierskim 1510-1663, Kielce 1991, s. 74-75. Wybór danych dla 1567 r. wynika z faktu, że autorka podała informację o cenie zbóż pochodzącą z inwentarza starostwa, a nie z lustracji. Na potrzeby przeliczeń przyjęto, że pojemność korca sandomierskiego wynosiła 58 litrów, a krakowskiego - 36-38 litrów (3 korce w ćwiertni).

${ }^{25}$ A. Wyczański, Studia nad gospodarką, Warszawa 1964, s. 60-62; J. Pelc, Ceny w Krakowie, s. 6-13. Przy przeliczaniu cen z lokalnych korców i ćwiertni założono, że pojemność korca z Nowego Miasta Korczyna wynosiła ok. 58 litrów, a korca krakowskiego - 36-38 litrów (3 korce w ćwiertni).
}

Drugim obok Małopolski regionem, dla którego w lustracyjnych kalkulacjach dochodowości folwarków królewskich zakładano jednolitą cenę zbóż, było województwo pomorskie. We wszystkich odnoszących się do niego wyliczeniach stosowano miarę gdańską. Przewidywane stawki wynosiły: 6 gr za korzec owsa, 13 gr za korzec żyta, 9 gr za korzec jęczmienia i 18 gr za korzec pszenicy. Tymczasem opracowane przez Pelca ceny gdańskie z lat 1563-1565 wynoszą: 4,5-8 gr za owies, 7,5-14 gr za żyto i 8-11 gr za jęczmień. W przypadku pszenicy skazani jesteśmy na pojedyncze informacje z późniejszego okresu. Z trzeciego kwartału 1566 r. mamy dane o cenie 29 gr za korzec, a z pierwszego kwartału 1567 - o 20 gr za korzec ${ }^{26}$. Alternatywnym źródłem informacji są tutaj inwentarze starostw malborskiego i tczewskiego, które w latach 1563-1565 rejestrują ceny za jeden korzec owsa na poziomie 5 gr, żyta - 11,7-13 gr, jęczmienia - 5,5-10 gr, a pszenicy - 12-21,3 $\mathrm{gr}^{27}$.

W przypadku lustracji wielkopolskiej z całą pewnością nie mamy do czynienia z próbami stosowania zunifikowanych cen czy miar. Ceny wyliczone w oparciu o lustracje są w tym regionie dość mocno zróżnicowane - wysokie na Kujawach i wokół Poznania, a wyjątkowo niskie na terenie części województw kaliskiego (miary konińska i gnieźnieńska) oraz sieradzkiego (miary radomszczańska i sieradzka). Widać to przede wszystkim w cenach owsa, a w mniejszym stopniu żyta i jęczmienia. Oczywiście można zadać pytanie o wiarygodność oszacowania pojemności miar wielkopolskich, a co za tym idzie - wyliczonych cen. Pewne obawy tego rodzaju istnieją w przypadku miar gnieźnieńskiej i konińskiej, gdyż podstawą do ich oszacowania były przede wszystkim wielkość omłotu z kopy oraz normy produkcji piwa. Wielkość miary sieradzkiej

\footnotetext{
${ }^{26}$ J. Pelc, Ceny w Gdańsku, s. 12-21, 145.

${ }^{27}$ J. Szpak, Rewolucja, s. 221-227.
} 
jest natomiast wynikiem przeliczenia jej relacji do miary gdańskiej ${ }^{28}$. $\mathrm{Na}$ dodatek ceny pszenicy na całym tym obszarze w zasadzie nie różnią się niczym od notowanych na terenach sąsiednich. Wydaje się więc, że w akcji lustracyjnej na terytorium Wielkopolski nie podejmowano żadnych działań unifikujących ceny, które miałyby usprawnić i zestandaryzować kalkulacje dochodowości folwarków. Pozostaje oczywiście pytanie o relacje cen podawanych w lustracjach do rynkowych. Brakuje tu zestawień cen z Poznania (ich opracowanie przerwała wojna) i innych ośrodków miejskich. Szczęśliwie jednak odnośnie do lat 1559-1570 dysponujemy cenami z leżących na styku województw sieradzkiego i łęczyckiego dóbr pabianickich (będących własnością kapituły krakowskiej), które możemy zestawić z cenami wyliczonymi dla funkcjonującej w bezpośrednim sąsiedztwie tych dóbr miary łęczyckiej. Wycena 100 litrów owsa tej miary wedle stawek zarejestrowanych w lustracji wyniosła 7,3 gr, żyta - 14,5 gr, jęczmienia $12,7 \mathrm{gr}$, a pszenicy - 29 gr. Tymczasem podawane przez Alinę Wawrzyńczykową dane z dóbr pabianickich wskazują, że w 1564 r. 100 litrów owsa kosztowało 7,3-10,1 gr, żyta - 14,5-20,3 gr, jęczmienia $-14,5 \mathrm{gr}$, a pszenicy $-29-33 \mathrm{gr}^{29}$.

Powyższe zestawienia cen zapisanych w lustracjach z wartościami rynkowymi zdają się wskazywać, że na większości ziem ruskich, Mazowszu i w dużej części Wielkopolski lustracje podają ceny zbóż zbliżone do minimalnych cen na rynkach lokalnych. Co prawda w odniesieniu do pszenicy spotykamy nawet dużo niższe niż minimalne, jednak liczba wzmianek o cenach tego zboża jest zwykle bardzo skromna i rozziew między ceną z lustracji a rynkową może wynikać z przypadkowości

\footnotetext{
${ }^{28}$ A. Wyczański, Studia nad konsumpcją żyności w Polsce w XVl i pierwszej połowie XVII w., Warszawa 1969, s, 23.

${ }^{29}$ A. Wawrzyńczykowa, Gospodarstwo dworskie w dobrach Pabianice 1559-1570, Wrocław-Warszawa-Kraków 1967, s. 169-170. Pojemność korca pabianickiego szacowana jest na 69 litrów.
}

informacji o tej ostatniej. Zastosowanie przez lustratorów w odniesieniu do terenów położonych w większej odległości od Gdańska, ale związanych z nim spławem zbóż, cen zbliżonych do minimalnych wypada uznać za zabieg racjonalny. Nie stał on bynajmniej w sprzeczności ze staraniami, by stosować tzw. ceny mierne, nie chodziło bowiem o cenę średnią, lecz dominującą na rynku. Pojawiające się w lustracjach sugestie o możliwości spławienia zboża do Gdańska i sfinansowania tej operacji z tzw. przymiarków, a więc różnicy między miarami lokalnymi a gdańską, nie były przez lustratorów nadmiernie rozbudowywane i nie zakładano w nich osiągnięcia w ten sposób jakichkolwiek nadzwyczajnych nadwyżek finansowych. Tego rodzaju działania wiązałyby się z pewnym ryzykiem, gdyż zboże zebrane w jednym roku można było spławić dopiero w następnym, i to bez pewności osiągnięcia ceny na tyle wysokiej, by różnica między cenami gdańską i lokalną zapewniła pokrycie kosztów spławu. Nawet jednak w najbardziej niesprzyjających okolicznościach sprzedaż zboża po finalnie niższej cenie w Gdańsku (po uwzględnieniu kosztów spławu) dawała możliwość zakupu w tym ośrodku różnego rodzaju towarów po cenach niższych niż w głębi kraju.

W przypadku Małopolski zestawienie cen widniejących w lustracjach z rzeczywistymi cenami zbytu zbóż zawartymi w inwentarzach dóbr królewskich wskazuje jednoznacznie, że opinia Ireny Rychlikowej była słuszna. Region ten zdecydowanie nie stanowił w okresie sporządzania lustracji zintegrowanego rynku zbożowego sięgającego od Krakowa po Lublin. Wypada więc zgodzić się z Rychlikową, że zastosowano tutaj strategię polegającą na wykorzystaniu minimalnej ceny z rynku krakowskiego jako stałej do szacowania dochodowości folwarków. Ceny z lustracji nie mówią więc nic o rynkach lokalnych, za wyjątkiem tego, że rzeczywiste ceny minimalne w Sandomierzu, Wiślicy czy Kazimierzu Dolnym 
były od nich z całą pewnością niższe. Przeprowadzenie takiego zabiegu zdecydowanie ułatwiło jednak lustratorom prowadzenie wszelkich szacunków finansowych.

$\mathrm{Na}$ terenie Prus Królewskich lustratorzy zastosowali odwrotny zabieg niż w Wielkopolsce, na Mazowszu i ziemiach ruskich, tzn. wykorzystanie w szacunkach cen maksymalnych. Można więc odnieść wrażenie, że mamy tu do czynienia $\mathrm{z}$ radykalnym zawyżeniem cen zboża przez nie najlepiej zorientowanych $\mathrm{w}$ miejscowych realiach lustratorów. Możliwe też jednak, że był to zupełnie świadomy zabieg. Bliskość gdańskiego rynku i jego dostępność przez cały rok (a nie tylko w sezonie spławu, jak dla sprzedawców z interioru Królestwa Polskiego) dawały możliwość elastycznego reagowania na zmiany cen i sprzedawania zboża w okresie zwyżek. W przypadku spławu z głębi Królestwa Polskiego czas dostawy na rynek gdański zależał od okresowych przyborów wód w górnych biegach dopływów Wisły (głównie Bugu i Narwi), wobec czego podaż rosła w określonym czasie, a wraz z nią musiały spadać ceny. W tym kontekście wyraźnie wyższe ceny

\section{Bibliografia}

Źródła publikowane

Inwentarz dóbr i dochodów biskupów poznańskich r. 1564, wyd. E. Długopolski, w: Archiwum Komisji Historycznej, seria 2, t. 3, Kraków 1939, s. 267-348.

Inwentarz dóbr $i$ dochodów biskupstwa wtoctawskiego z r. 1534, wyd. B. Ulanowski, Kraków 1902.

Inwentarz dóbr stotowych biskupstwa wtoctawskiego z roku 1582, wyd. L. Żytkowicz, Torun 1953.

Inwentarz dóbr stotowych biskupstwa wtoctawskiego z roku 1598, wyd. L. Żytkowicz, Torun 1950.

Lustracja województw malborskiego i chetmińskiego 1565, wyd. S. Hoszowski, Gdańsk 1961.

Lustracja województw wielkopolskich i kujawskich 1564 1565, cz. 1-2, wyd. A. Tomczak, C. Ohryzko-Włodarska, J. Włodarczyk, Bydgoszcz 1961.

Lustracja województw wielkopolskich i kujawskich 1616-1620, cz. 1-2, wyd. Z. Górski, R. Kabaciński, J. Pakulski, Wrocław-Warszawa-Kraków 1994. zbóż w lustracjach z terenu Kujaw w porównaniu do zlokalizowanych tuż obok ziem mazowieckich mogą wynikać także z takiej właśnie kalkulacji, zakładającej ułatwiony dostęp do rynku gdańskiego.

Reasumując, wypada sformułować dużo bardziej optymistyczną opinię o przydatności badawczej cen zbóż zawartych w lustracjach, niż sugerowała Irena Rychlikowa. Co prawda w przypadku Małopolski, Pomorza i ziem ruskich położonych w bezpośrednim sąsiedztwie Bugu rzeczywiście mamy do czynienia $\mathrm{z}$ odgórnym unifikowaniem cen przez lustratorów, ale na Mazowszu, w Wielkopolsce i większości ziem ruskich tego rodzaju zabiegów nie dokonywano. W tamtejszych szacunkach zastosowane zostały ceny rynkowe zbliżone do minimalnych, we właściwy sposób odpowiadające pojęciu tzw. ceny miernej, co pozwala na obserwowanie relacji cen między poszczególnymi rynkami lokalnymi. Zabiegi unifikacyjne o ile miały miejsce - polegały raczej na ujednolicaniu cen w ramach jednej miary lokalnej, a nie w obrębie dużych regionów geograficznych.
Lustracja województw wielkopolskich $i$ kujawskich 1628-1632, cz. 1-2, wyd. Z. Guldon, WrocławWarszawa-Kraków 1967.

Lustracja województw wielkopolskich $i$ kujawskich 16281632, cz. 3, wyd. Z. Guldon, Bydgoszcz 1967.

Lustracja województwa krakowskiego 1564, cz. 1-2, wyd. J. Małecki, Warszawa 1962.

Lustracja województwa lubelskiego 1565, wyd. A. Wyczański, Wrocław-Warszawa 1959.

Lustracja województwa mazowieckiego 1565, cz. 1-2, wyd. I. Gieysztorowa, A. Żaboklicka, Warszawa 1967.

Lustracja województwa pomorskiego 1565, wyd. S. Hoszowski, Gdańsk 1961.

Lustracja województwa sandomierskiego 1564-1565, wyd. W. Ochmański, Wrocław-Warszawa-Kraków 1963.

Lustracje województwa ptockiego 1565-1789, wyd. A. Sucheni-Grabowska, S.M. Szacherska, Warszawa 1965. 
Lustracje województwa rawskiego 1565 i 1570, wyd. Z. Kędzierska, Warszawa 1959.

Архивъ югго-западной Россіи, ч. 7, т. 2, Кіевъ 1890.

Жерела до істориї України-Руси, т. 1, реА. М. Грушевський,

\section{Opracowania}

VIII Powszechny Zjazd Historyków Polskich. Referaty $i$ dyskusje, t. 2: Historia gospodarcza Polski, red. N. Gąsiorowska, Warszawa 1960.

Adamczyk W., Ceny w Lublinie od XVI do końca XVIII wieku, Lwów 1935.

Adamczyk W., Ceny w Warszawie w XVI i XVII wieku, Lwów 1938.

Falniowska-Gradowska A., Miary zbożowe w województwie krakowskim w XVIII w., „Kwartalnik Historii Kultury Materialnej”, 13 (4), 1965, s. 663-688.

Furtak T., Ceny w Gdańsku w latach 1701-1815, Lwów 1935.

Gurgul J., Ceny czterech podstawowych zbóż w XVI wieku. Próba porównania, „Rocznik Muzeum Narodowego Rolnictwa w Szreniawie”, 17, 1989, s. 319-337.

Hoszowski S., Ceny we Lwowie w XVI i XVII wieku, Lwów 1928.

Hoszowski S., Rewolucja cen w Polsce w XVI-XVII wieku, w: VIII Powszechny Zjazd Historyków Polskich. Referaty i dyskusje, t. 2: Historia gospodarcza Polski, red. N. Gąsiorowska, Warszawa 1960, s. 105-120.

Hoszowski S., Rewolucja cen w środkowej Europie w XVI i XVII w., „Kwartalnik Historyczny”, 68 (2), 1961, s. 297-312.

Madurowicz-Urbańska H., Ceny zboża w zachodniej Matopolsce w drugiej potowie XVIII wieku, Warszawa 1963.

Mączak A., Ceny jako wyznacznik powiązań rynkowych: na marginesie prac H. Madurowicz-Urbańskiej i S. Mielczarskiego, „Kwartalnik Historii Kultury Materialnej”, 12 (1), 1964, s. 95-112.

Mączak A., Ceny, ptace i koszty utrzymania w Europie Srodkowej. Wposzukiwaniu nowych źródet do dziejów XVI wieku, „Przegląd Historyczny”, 64 (4), 1973, s. 741-769.

Mączak A., Export of grain and the problem of distribution of national income in the years 1550-1650, „Acta Poloniae Historica”, 18, 1968, s. 75-98.

Mączak A., Pieniądz i spoteczeństwo w Rzeczpospolitej XVI-XVII wieku, „Roczniki Dziejów Społecznych i Gospodarczych", 37, 1977, s. 63-85.

Mączak A., Ptace i pieniądze w gospodarce rolnej Polski XVI-XVII wieku. Problem niedoceniany, „Zapiski Historyczne", 41 (3), 1976, s. 51-65.
Жерела до істориї Украӥни-Руси, т. 2, реА. М. Грушевський, $\Lambda$ ьвів 1897.

Жерела до істориї Украӥни-Руси, т. 3, реА. М. Грушевський, Аьвів 1900.

Mączak A., Z metodyki badań rynku w XVI-XVII wieku. Uwagi polemiczne, „Kwartalnik Historii Kultury Materialnej”, 12 (4), 1964, s. 681-707.

Mielczarski S., Rynek zbożowy na ziemiach polskich w drugiej potowie XVI i pierwszej potowie XVII wieku. Próba rejonizacji, Gdańsk 1962.

Muszyńska J., Gospodarstwo chtopskie w starostwie sandomierskim 1510-1663, Kielce 1991.

Pelc J., Cenyw Gdańsku w XVI i XVII wieku, Lwów 1937.

Pelc J., Ceny w Krakowie w latach 1369-1600, Lwów 1935.

Rychlikowa I., Lustracja 1564-1566 jako podstawa szacunków dochodów z gospodarki polowej, „Kwartalnik Historii Kultury Materialnej”, 22 (4), 1974, s. 673-716.

Rychlikowa I., Niektóre zagadnienia metodyczne w badaniach cen i rynku $w$ drugiej potowie XVIII wieku, „Kwartalnik Historii Kultury Materialnej”, 12 (3), 1964, s. 375-409.

Stownik polszczyzny XVI wieku, red. M.R. Mayenowa, t. 14, Wrocław-Warszawa-Kraków-Gdańsk-Łódź 1982.

Szpak J., Rewolucja cen XVI wieku a funkcjonowanie gospodarki dworskiej w starostwach Prus Królewskich, Kraków 1982.

Tomaszewski E., Ceny w Krakowie w latach 16011795, Lwów 1934.

Topolski J., Gospodarstwo wiejskie w dobrach arcybiskupstwa gnieźnieńskiego od XVI do XVIII wieku, Poznań 1958.

Wawrzyńczykowa A., Gospodarstwo dworskie w dobrach Pabianice 1559-1570, Wrocław-Warszawa-Kraków 1967.

Wolański M., Ceny we Wroctawiu w latach 1506-1618, Wrocław 1996.

Wolański M., Ceny zboża i jego przetworów oraz owoców $i$ warzyw we Wroctawiu w latach 1506-1618, Wrocław 1993.

Wyczański A., Studia nad folwarkiem szlacheckim $w$ Polsce $w$ latach 1500-1580, Warszawa 1960.

Wyczański A., Studia nad gospodarka starostwa korczyńskiego 1500-1660, Warszawa 1964.

Wyczański A., Studia nad konsumpcją żywności w Polsce w XVI i pierwszej potowie XVII w., Warszawa 1969. 


\section{Spatial Diversification of Prices of Rye, Wheat, Barley, and Oats in the Kingdom of Poland in the Lustration of Royal Estates between 1564 and 1565}

\section{Summary}

The article focuses on two objectives. First one is the creation of a price list of grain (wheat, rye, barely, and oat) for the whole Kingdom of Poland in 1564. The list has been created using data from inspection surveys of the crown lands prepared in 1564-1565. The second aim is the verification of credibility of these prices, because their reliability was questioned in Polish historiography in the past.

All data about the grain prices were recalculated from local measures to one hectolitre (100 litres) as standard unit allowing to compare collected data for the entire territory of the Kingdom of Poland. Verification of credibility indicated that, as was argued by Irena Rychlikowa in the past, for two large regions of Little Poland and Royal Prussia the prices of grain were intentionally unified. For Little Poland officials adopted the minimal grain price from Kraków market from the year 1564. For Royal Prussia,

it was the highest price from Gdańsk's market from the same year. But we should not treat this operation made by $16^{\text {th }}$-century's officials as something lowering reliability of all data. This operation was justified, as Kraków was the main market of grain for biggest part of Little Poland, and Gdańsk was the main market for the whole Royal Prussia. The lowest and the highest prices for both regions were the effect of different accessibility to the market and costs of transportation. For Little Poland, the cost of transportation was higher due to the use of land roads and horse-wagons. In Royal Prussia, costs were lower due to the access to the Vistula River, offering much cheaper transportation and quite easy access to the market for almost the whole year. For other regions of the Kingdom of Poland, officials were using usually the lowest prices uniformed for every locally employed cubic measures.

dr hab. Krzysztof Boroda - pracownik Wydziału Historii i Stosunków Międzynarodowych Uniwersytetu w Białymstoku oraz Zakładu Atlasu Historycznego w Instytucie Historii PAN. W swoich badaniach skupia się na historii gospodarczej i społecznej oraz geografii historycznej (kbrda@wp.pl)

Krzysztof Boroda, Dr. hab. - employed at the Faculty of History and International Affairs, University of Białystok, and at the Department of Historical Atlas at the Tadeusz Manteuffel Institute of History, Polish Academy of Sciences. In his research he focuses on economic and social history, and historical geography (kbrda@wp.pl) 